\title{
Centigray per Fraction
}

National Cancer Institute

\section{Source}

National Cancer Institute. Centigray per Fraction. NCI Thesaurus. Code C159626.

A unit of absorbed radiation dose equal to the number of centigrays per fraction. 